\title{
ENVIRONMENTAL BALANCE OF AN INNOVATIVE WASTE-TO-ENERGY PLANT: THE ROLE OF SECONDARY EMISSIONS
}

\author{
MARCO SCHIAVON $^{1}$, LUCA ADAMI ${ }^{1}$, VINCENZO TORRETTA ${ }^{2} \&$ MARCO TUBINO $^{1}$ \\ ${ }^{1}$ Department of Civil, Environmental and Mechanical Engineering, University of Trento, Trento, Italy \\ ${ }^{2}$ Department of Theoretical and Applied Sciences, University of Insubria, Varese, Italy
}

\begin{abstract}
In spite of their positive role in the framework of circular economy, waste-to-energy processes are responsible for the emissions of a large number of air pollutants. Although this sector has made significant improvements in the air pollution control of primary emissions, the role of other sources (i.e. secondary emissions) has been often neglected. This paper aims at investigating the contributions of primary and secondary emissions expected from a waste gasification plant that is planned for the construction in an Alpine valley. The results from this analysis show that secondary emissions would play a significant role in the overall emissive footprint of the plant, contributing to $29 \%$ and $10 \%$, respectively, of the overall emissions of dusts and total organic carbon. In the light of such results, secondary emissions would require an appropriate monitoring approach, which should complement the existing monitoring protocols for primary emissions.
\end{abstract}

Keywords: air pollutants, environmental impact assessment, environmental monitoring, gasification, waste management.

\section{INTRODUCTION}

Waste to energy (WtE) processes allow converting residual waste into electric energy and (optionally) thermal energy, thus considerably reducing the flow of waste sent to landfill $[1,2]$. Considered that the average heating value of solid waste is estimated as being approximately $10 \mathrm{MJ} / \mathrm{kg}[3,4]$, the choice of exploiting the energy value of waste comes naturally. The advantages given by the exploitation of waste residues as a source for energy production go beyond the simple generation of electric energy and thermal energy from end-of-life products. The transformation of waste into energy allows increasing the lifetime and the values of resources, reducing waste and the use of resources at their minimum [3]. In particular, if WtE plants are properly inserted in a context of integrated waste management, the $\mathrm{WtE}$ sector can close the loop from the point of view of both material and energy recovery and being in concordance with the circular economy (CE) requests [5,6]. For instance, a well-designed integrated waste management system would consider bio-stabilisation, which acts on the fraction of non-recyclable municipal solid waste (residual fraction), generating both non-putrescible material from the organic fraction and refuse-derived fuel (RDF) from the inorganic one. This way, the stabilised organic fraction can be used as a landfill coverage material or for landscape purposes, thus minimising the production of greenhouse gases (GHGs) from landfills, while RDF or solid recovered fuel (SRF) can be used as a fuel in WtE processes, closing the loop also from the point of view of energy [7,8]. In this sense, the WtE sector properly complies with the concept of $\mathrm{CE}$, which represents a reaction to the inefficiency of the traditional concept of linear economy in terms of resource management and also helps to achieve sustainable development goals $[9,10]$. Specifically, indirect combustion of $\mathrm{RDF} / \mathrm{SRF}$ (i.e. gasification of RDF and combustion of the syngas generated by gasification), 
if properly coupled with strategies for bottom ash valorisation (e.g. vitrification), has been recently depicted as the preferred option in a CE perspective [11]. A life-cycle assessment study, developed in a recent work, also highlighted that a WtE scenario would perform better than a recycling scenario from several points of view, thanks to the reduced secondary waste streams (which might increase eutrophication and human toxicity potentials) and to the lower use of fossil fuels with respect to recycling processes [12]. Conversely, if considered as completely separated scenarios, higher impacts are expected from the point of view of GHG emissions with respect to recycling, but those can be minimised if synergies between the two scenarios are pursued in an integrated waste management perspective.

In spite of their crucial role in integrated waste management systems and in view of a CE perspective, WtE plants emit various groups of air pollutants into the atmosphere. Being based on the combustion, pyrolysis or gasification of solid fuels, WtE plants are emission sources of particulate matter, heavy metals, dioxin, polycyclic aromatic hydrocarbons (PAHs) and gaseous air pollutants like nitrogen oxides (NOx), sulphur oxides (SOx), carbon monoxide (CO), ammonia $\left(\mathrm{NH}_{3}\right)$, volatile organic compounds, hydrogen chloride $(\mathrm{HCl})$ and hydrogen fluoride (HF), whose mass flow rates may differ depending on the type of input waste and on the process [13-15]. Differently from waste direct combustion processes, indirect combustion consists in a thermal treatment typically of RDF/SRF carried out in the absence (pyrolysis) or limited presence (gasification) of oxygen to ensure reducing or slightly oxidising conditions that decompose the primary fuel and generate the so-called syngas, i.e. a mixture of hydrogen, $\mathrm{CO}$, carbon dioxide, water vapour, nitrogen and hydrocarbons, which is burned in a combustion chamber to produce thermal energy and electric energy by boilers and gas turbines [16]. In the gasification process, the gaseous and particulate residues of syngas combustion and RDF/SRF gasification are released into the atmosphere by a stack. Compared to direct combustion, gasification ensures lower emissions, thanks to more uniform combustion conditions, higher energy efficiency, higher temperature and reduced oxygen content $[17,18]$.

However, the primary stack is not the only emission source from WtE plants: depending on the processes in use, there may be a variable number of different additional emission sources that can release air pollutants. Such secondary minor emission sources may entail a non-negligible and significant impact on the environment. In addition to the emissions that originate from road transport (e.g. the supply of RDF/SRF to a WtE plant and/or the removal of combustion/gasification solid residues), other emissions may be related to activities regarding the management of the incoming waste, of the slag/ashes generated by the combustion process, of the reaction products of the air pollution control system and of the energy conversion technology in use (e.g. turbines). The literature on the WtE sector lacks of publications on the role that secondary emissions may play in the overall emissive footprint of WtE plants. Both primary and secondary emissions should be carefully taken into account during the authorisation procedure of new plants, which should be compatible with the presence of other civil or industrial activities already in operation in the area and with the overall local impacts on the population and the environment.

In the European Union, the emissions from WtE plants are regulated by the European Directive 2010/75/EU [19]. The authorisation processes of a WtE plant is regulated by the European Directive 2014/52/EU that reviewed the Directive 2011/92/EU in several aspects: 'purely' procedural requirements, screening, quality and monitoring [20-22]. Although the cumulative effects of environmental impacts have been introduced in the European legislation since the 1980 s of the last century with the Directive $85 / 337 / \mathrm{EEC}$, only rarely the 
combined effect due to the presence of secondary emission sources and of existing civil or industrial activities has been considered in the monitoring phase and in the compensation strategy [23,24].

In the present paper, we analyse the effects of the secondary emissions of a WtE plant that is planned for construction in the Alpine area of Italy and we propose a compensation strategy that considers to intervene not only on the plant in project, but also on the possible modifications to the authorisations of existing or no longer operational plants.

\section{MATERIAL AND METHODS}

In order to exemplify the issue of secondary emissions from $\mathrm{WtE}$ plants, the case of a waste thermal treatment plant is presented here. The plant is currently under evaluation by the local environmental authority for authorisation [25]. The waste management company that proposed the construction of the plant intends to build this in an Alpine valley in the north of Italy. The plant would be located at about $800 \mathrm{~m}$ from the eastern slope of the valley, which is oriented North-South and is 2.6-km wide at the cross-section passing through the hypothetical location of the plant. The plant's location would be an industrial area, with about 10 pre-existing industrial activities, surrounded by cultivated fields, primarily vineyards and apple orchards. The plant would be located about 600-m west from a Site of Community Importance defined by the European Commission. Small villages are present in the stretch of valley considered, at distances $>1.4 \mathrm{~km}$ from the hypothetical location of the plant (Fig. 1). At the plant's location, the wind mainly originates from East-Northeast and South-Southeast.

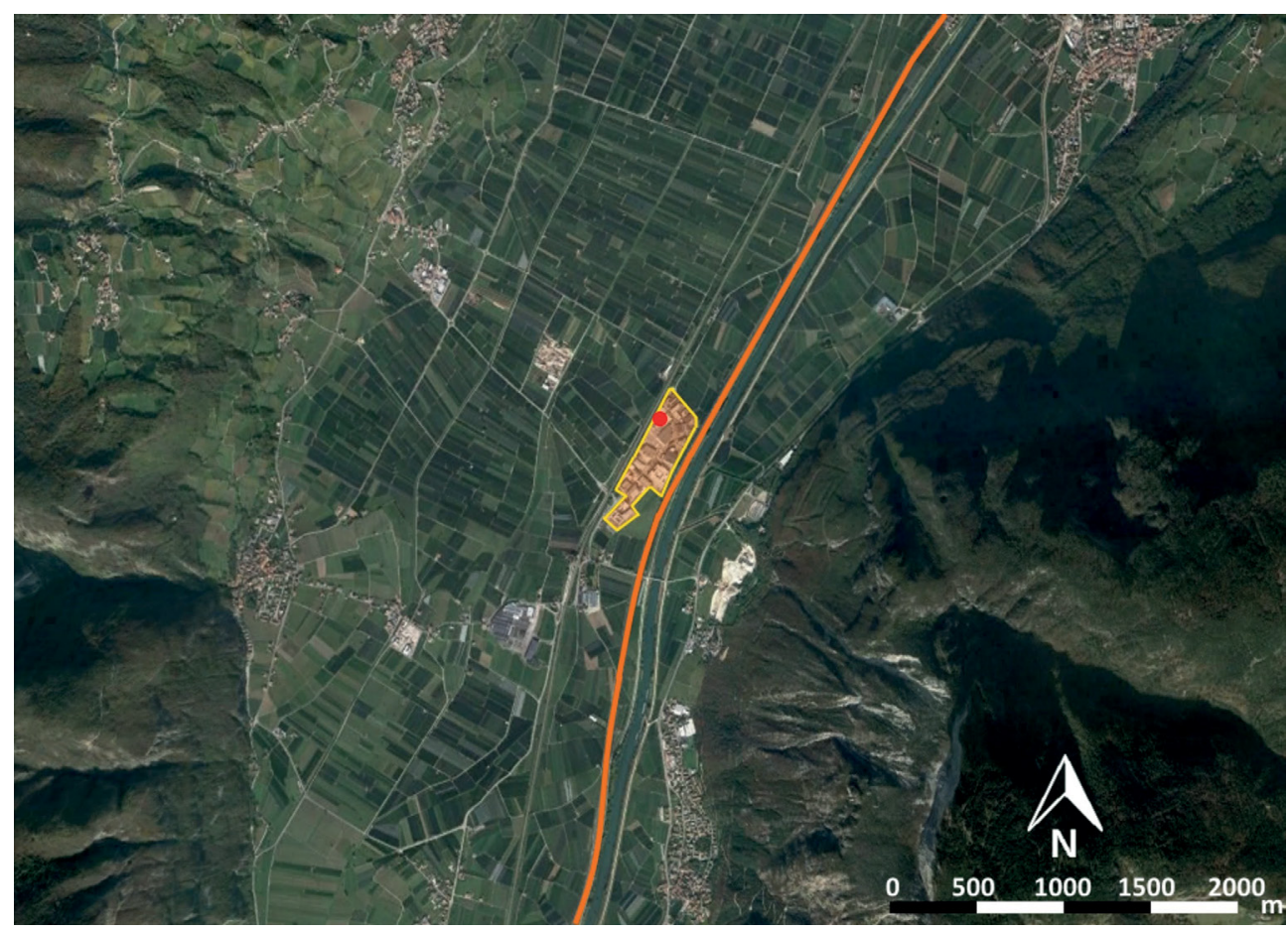

Figure 1: Details of the hypothetical location of the WtE plant (red dot), of the industrial area (yellow polygon) and of the highway (orange line) [26]. 
The plant is designed to treat 95,000 t/year of RDF (European Waste Catalogue - EWC code 1912 10), other non-hazardous wastes from mechanical treatment of wastes (EWC code 1912 12) and minor contributions from other industrial wastes. The plant is able to perform the gasification of the input waste, the combustion of the syngas, the production of thermal energy through a boiler and the conversion to electric energy through a turbine. In addition, the peculiarity of this plant is the ability to carry out the vitrification of the residues of waste gasification contemporarily to the gasification process itself. To do this, coke is inserted (with a mass flow rate of 5,000 t/year) as an auxiliary fuel to allow increasing the temperature to about $1,600^{\circ} \mathrm{C}-2,000^{\circ} \mathrm{C}$ in the bottom part of the reactor. The syngas combustion is carried out in a secondary upper compartment integrated in the main combustion chamber, where the input waste and the coke are inserted. Methane is used as the auxiliary fuel to initially ignite the syngas. The maximum thermal power of the plant is $69 \mathrm{MW}$, enabling the use of a turbo generator with nominal capacity of $17 \mathrm{MW}_{\mathrm{el}}$, which is estimated to produce about $100 \mathrm{GWh} /$ year of electric energy. The thermal line is equipped with a heat recovery system. The exhaust gas, whose volumetric flow rate would be $107,000 \mathrm{Nm}^{3} / \mathrm{h}$, is released by a $45-\mathrm{m}$ high stack with a diameter of $1.8 \mathrm{~m}$, at a temperature of $130^{\circ} \mathrm{C}$ or $181^{\circ} \mathrm{C}$, in case the thermal energy is recovered for district heating or not, respectively. Before leaving the stack, the exhaust gas passes through a cyclone for coarse particle removal, a first bag filter with the injection of sodium bicarbonate and activated carbon to abate chlorine- and sulphur-containing compounds, a Venturi scrubber for acidic gas removal, a second bag filter and a selective catalytic reduction system. The ashes recovered by the cyclone and the reaction products are stored in two separated silos.

In Europe, WtE plants must comply with the Directive 2010/75/EU concerning the concentration limit values of several air pollutants at the stack level [19]. Specifically, limit values are set for the following pollutants: total suspended particles (TSP), total organic carbon (TOC), $\mathrm{HCl}, \mathrm{HF}$, sulphur dioxide $\left(\mathrm{SO}_{2}\right), \mathrm{NOx}, \mathrm{CO}, \mathrm{NH}_{3}$, cadmium and thallium $(\mathrm{Cd}+\mathrm{Tl}$ ), mercury $(\mathrm{Hg})$, other heavy metals as a group (arsenic, antimony, cobalt, chromium, nickel, lead, manganese and vanadium), PAHs, dioxins and furans (PCDD/Fs) and polychlorinated biphenyls (PCBs). For the case study, the proponent ensures the compliance of the plant with lower limit values, as reported in Table 1.

As anticipated, in addition to the main stack (which generates primary emissions, E1), every WtE plant has additional emission sources leading to secondary emissions of air pollutants. In the case object of this study, secondary emission streams consist in:

- the vent of the silo dedicated to the storage of the ashes recovered by the cyclone (E2a);

- the vent of the silo dedicated to the storage of the sodium-based reaction products (E2b);

- the discharge of the air blown from the chamber collecting the incoming waste (E3);

- the emergency electrical generator (E4);

- the discharge of the aspiration system of dusts from the indoor spaces (E5);

- the discharge of the aspiration system of oily aerosols from the compartment of the turbo generator (E6).

Table 2 reports the characteristics of the secondary emission sources and the concentration limit values of the emissions of the expected air pollutants. In the case of E3, the plant would be able to ensure lower concentration values of TSP and TOC than the concentration limit values set by the Directive 2010/75/EU [19].

Since the electrical generator is supposed to operate only in emergency situations, it is reasonable to neglect E4 from the potential contributions of secondary emissions to the overall emissions of the plant. 
Table 1: Regulatory limit values and guaranteed limit values for the pollutants released by the stack as regulated by the Directive 2010/75/EU [19,25].

\begin{tabular}{|c|c|c|c|}
\hline Pollutant & $\begin{array}{l}\text { Concentration limit } \\
\text { value }\end{array}$ & Guaranteed limit value & Averaging period \\
\hline \multirow[t]{2}{*}{ TSP } & $10 \mathrm{mg} / \mathrm{Nm}^{3}$ & $1.5 \mathrm{mg} / \mathrm{Nm}^{3}$ & $24 \mathrm{~h}$ \\
\hline & $30 \mathrm{mg} / \mathrm{Nm}^{3}$ & $16 \mathrm{mg} / \mathrm{Nm}^{3}$ & $30 \min ^{\mathrm{a}}$ \\
\hline \multirow[t]{2}{*}{ TOC } & $10 \mathrm{mg} / \mathrm{Nm}^{3}$ & $10 \mathrm{mg} / \mathrm{Nm}^{3}$ & $24 \mathrm{~h}$ \\
\hline & $20 \mathrm{mg} / \mathrm{Nm}^{3}$ & $18 \mathrm{mg} / \mathrm{Nm}^{3}$ & $30 \min ^{\mathrm{a}}$ \\
\hline \multirow[t]{2}{*}{$\mathrm{HCl}$} & $10 \mathrm{mg} / \mathrm{Nm}^{3}$ & $2 \mathrm{mg} / \mathrm{Nm}^{3}$ & $24 \mathrm{~h}$ \\
\hline & $60 \mathrm{mg} / \mathrm{Nm}^{3}$ & $50 \mathrm{mg} / \mathrm{Nm}^{3}$ & $30 \min ^{\mathrm{a}}$ \\
\hline \multirow[t]{2}{*}{$\mathrm{HF}$} & $1 \mathrm{mg} / \mathrm{Nm}^{3}$ & $0.25 \mathrm{mg} / \mathrm{Nm}^{3}$ & $24 \mathrm{~h}$ \\
\hline & $4 \mathrm{mg} / \mathrm{Nm}^{3}$ & $4 \mathrm{mg} / \mathrm{Nm}^{3}$ & $30 \min ^{\mathrm{a}}$ \\
\hline \multirow[t]{2}{*}{$\mathrm{SO}_{2}$} & $50 \mathrm{mg} / \mathrm{Nm}^{3}$ & $10 \mathrm{mg} / \mathrm{Nm}^{3}$ & $24 \mathrm{~h}$ \\
\hline & $200 \mathrm{mg} / \mathrm{Nm}^{3}$ & $180 \mathrm{mg} / \mathrm{Nm}^{3}$ & $30 \min ^{\mathrm{a}}$ \\
\hline \multirow[t]{2}{*}{ NOx } & $200 \mathrm{mg} / \mathrm{Nm}^{3}$ & $40 \mathrm{mg} / \mathrm{Nm}^{3}$ & $24 \mathrm{~h}$ \\
\hline & $400 \mathrm{mg} / \mathrm{Nm}^{3}$ & $150 \mathrm{mg} / \mathrm{Nm}^{3}$ & $30 \min ^{\mathrm{a}}$ \\
\hline \multirow[t]{2}{*}{$\mathrm{CO}$} & $50 \mathrm{mg} / \mathrm{Nm}^{3}$ & $50 \mathrm{mg} / \mathrm{Nm}^{3}$ & $24 \mathrm{~h}$ \\
\hline & $150 \mathrm{mg} / \mathrm{Nm}^{3}$ & $130 \mathrm{mg} / \mathrm{Nm}^{3}$ & $30 \min ^{\mathrm{a}}$ \\
\hline \multirow[t]{2}{*}{$\mathrm{NH}_{3}$} & $30 \mathrm{mg} / \mathrm{Nm}^{3}$ & $10 \mathrm{mg} / \mathrm{Nm}^{3}$ & $24 \mathrm{~h}$ \\
\hline & $60 \mathrm{mg} / \mathrm{Nm}^{3}$ & $60 \mathrm{mg} / \mathrm{Nm}^{3}$ & $30 \min ^{\mathrm{a}}$ \\
\hline $\mathrm{Cd}+\mathrm{Tl}$ & $0.05 \mathrm{mg} / \mathrm{Nm}^{3}$ & $0.025 \mathrm{mg} / \mathrm{Nm}^{3}$ & $8 \mathrm{~h}$ \\
\hline $\mathrm{Hg}$ & $0.05 \mathrm{mg} / \mathrm{Nm}^{3}$ & $0.025 \mathrm{mg} / \mathrm{Nm}^{3}$ & $8 \mathrm{~h}$ \\
\hline Other heavy metals & $0.5 \mathrm{mg} / \mathrm{Nm}^{3}$ & $0.25 \mathrm{mg} / \mathrm{Nm}^{3}$ & $1 \mathrm{~h}$ \\
\hline PAHs & $0.01 \mathrm{mg} / \mathrm{Nm}^{3}$ & $0.01 \mathrm{mg} / \mathrm{Nm}^{3}$ & $8 \mathrm{~h}$ \\
\hline $\mathrm{PCDD} / \mathrm{Fs}$ & $0.1 \mathrm{ng}-\mathrm{ITEQ} / \mathrm{Nm}^{3}$ & $0.025 \mathrm{ng}-\mathrm{ITEQ} / \mathrm{Nm}^{3}$ & $8 \mathrm{~h}$ \\
\hline PCBs & $0.1 \mathrm{ng}-\mathrm{ITEQ} / \mathrm{Nm}^{3}$ & $0.1 \mathrm{ng}-\mathrm{ITEQ} / \mathrm{Nm}^{3}$ & $8 \mathrm{~h}$ \\
\hline
\end{tabular}

${ }^{\mathrm{a}}$ In a $24-\mathrm{h}$ period.

\section{RESULTS AND DISCUSSION}

The characteristics of the secondary emissions presented in Table 2 can now be summarised in terms of mass flow rate of the emitted categories of pollutants. In order to compare the contributions of secondary emissions with the primary emissions, the mass flow rates of the same categories of pollutants considered for E2-E6 (with the exclusion of E4) were calculated for E1 (Table 3). The mass flow rates for E1 were calculated in terms of the concentration values guaranteed by the plant (Table 1) and by considering the normalisation of the stack concentrations of TSP and TOC to the estimated oxygen percentage of the exhaust gas $(6.4 \%)$. Guaranteed stack concentrations were considered also for TSP from E3 and E5, while the concentrations of TOC and of TSP related to the remaining emissions sources were regarded as limit values, according to the Directive 2010/75/EU [19], in the absence of more precise information on the performance of the plant. Furthermore, in the case of E3, the mass 
Table 2: Characteristics of the secondary emission sources and the concentration limit values (on a daily basis) of the emissions of the expected air pollutants [19].

\begin{tabular}{lcclcc}
\hline $\begin{array}{l}\text { Emission } \\
\text { source }\end{array}$ & $\begin{array}{l}\text { Airflow rate } \\
{\left[\mathrm{Nm}^{3} / \mathrm{h}\right]}\end{array}$ & $\begin{array}{l}\text { Emission } \\
\text { frequency } \\
{[\text { h/year }]}\end{array}$ & Pollutant & $\begin{array}{l}\text { Concentration limit } \\
\text { value }\left[\mathrm{mg} / \mathrm{Nm}^{3}\right]\end{array}$ & $\begin{array}{l}\text { Height of release } \\
\text { point }[\mathrm{m}]\end{array}$ \\
\hline E2a & 500 & 8,760 & TSP & 10 & 23.0 \\
E2b & 500 & 8,760 & TSP & 10 & 21.0 \\
E3 & $10,000^{\mathrm{a}}$ & 1,000 & TSP & $2^{\mathrm{b}}$ & \\
& & & TOC & 10 & 41.5 \\
& $68,150^{\mathrm{c}}$ & 1,368 & TSP & $2^{\mathrm{b}}$ & \\
E5 & 31,000 & & TOC & 10 & 41.5 \\
E6 & 100 & 8,760 & TSP & $2^{\mathrm{b}}$ & 10.0 \\
\hline
\end{tabular}

${ }^{a}$ During maintenance periods, the air extracted from the waste chamber is released into the atmosphere after mechanical filtration and activated carbon adsorption.

${ }^{\mathrm{b}}$ Values guaranteed by the plant.

${ }^{\mathrm{c}}$ During normal operation of the plant, the air extracted from the waste chamber is used as combustive agent in the combustion chamber, after mechanical filtration.

flow rates of TSP and TOC reported in Table 3 consider the sum of the annual contributions from the emissions related to normal operation and to maintenance periods. Only in the case of normal operation, the stack concentrations from E3 $\left(2 \mathrm{mg} / \mathrm{Nm}^{3}\right.$ and $10 \mathrm{mg} / \mathrm{Nm}^{3}$ for TSP and TOC, respectively) were corrected on the basis of the oxygen content of the exhaust gas.

For a better visualisation of the role of secondary emissions, Fig. 2 reports the percentage contributions of E1-E6 (with the exclusion of E4) to the total mass flow rates of TSP and TOC. For the present case study, secondary emissions would contribute, in total, to $29 \%$ and $10 \%$ of the overall emissions of TSP and TOC by the waste gasification plant, respectively. The contributions of E2a, E2b and E6 are not significant with respect to the authorised total

Table 3: Mass flow rates of TSP and TOC from all the emission sources of the plant.

\begin{tabular}{llc}
\hline Emission source & Pollutant & Mass flow rate [t/year] \\
\hline E1 & TSP & 2.053 \\
E2a & TOC & 13.685 \\
E2b & TSP & 0.044 \\
E3 & TSP & 0.044 \\
& TSP & 0.292 \\
E5 & TOC & 1.461 \\
E6 & TSP & 0.458 \\
All secondary emissions & TSP & 0.009 \\
& TSP & 0.847 \\
& TOC & 1.461 \\
\hline
\end{tabular}



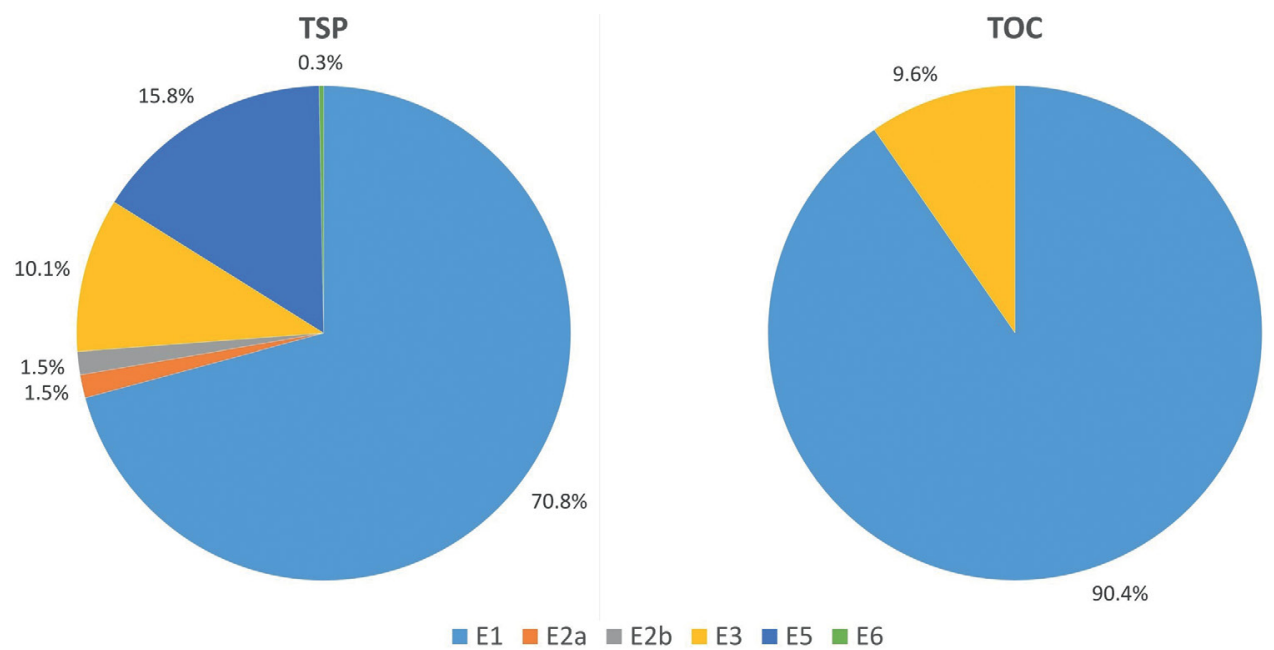

Figure 2: Percentage contributions of primary and secondary emission sources in terms of TOC and TSP.

emissions of TSP from the plant. However, E3 and E5 can generate emissions of TSP and TOC (only for E3) that cannot be neglected when estimating the overall footprint of the plant.

Such considerations let conclude that a monitoring activity should be implemented to keep secondary emissions under control, in the light of the fact that their contribution cannot be neglected when considering the overall impacts from a WtE plant. In addition, the emission sources E3 and E6 are characterised by lower release heights in comparison with E1. Consequently, the atmospheric dispersion of the pollutants released by secondary emissions might be weaker with respect to the effluent from the primary stack. The more a WtE plant performs well in terms of removal of air pollutants from the air pollution control system of the primary stack, the higher contribution is expected from secondary emissions. The monitoring of secondary emissions could be part of the environmental monitoring plan that must be drafted during the environmental impact assessment procedure.

The evolution of the technology in the sector of $\mathrm{WtE}$ plants, integrated with adequate mitigations, can allow reaching a level of environmental impact that can be negligible locally and could help to increase the level of acceptance of these plants by the community [27,28]. In this context, the role of compensations of primary and secondary emissions is crucial, opening also to interesting opportunities for the territory [11] in terms of local compensations (e.g. introducing criteria of pollution-offset trade, supporting zero landfill strategies, introducing traditional or electric district heating), and of global compensations (e.g. through carbon capture or purchasing $\mathrm{CO}_{2}$ emissions quotas).

Moreover, the design of a new WtE plant should consider the possibility to be settled in existing areas substituting industrial activities (many are the cases of closed factories with active permissions to emit).

\section{CONCLUSIONS}

In the light of the considerations expressed above, secondary emissions from WtE plants may give significant contributions to the overall emissions of air pollutants from this sector. In the presented case study, the secondary emissions of TSP and TOC account for $41 \%$ and $11 \%$ 
of the corresponding primary emissions, respectively. A deeper knowledge of the guaranteed emission values from secondary emissions (E2a, E2b and E6, in this case) would slightly decrease these contributions. Different percentages are expected from different plants, since secondary emissions depend on the waste combustion technology in use, on the management of the incoming waste, on the type of input waste and on the air pollution control system. The latter might change from plant to plant. Thus, the comparison of secondary emissions with the primary emissions may change case by case. The implementation of an environmental monitoring plan for secondary emissions (at least for the emission sources that are believed to contribute significantly to the overall emissions from a plant) would help both keeping additional emission sources under control and deriving emission factors that could be conveniently adopted in dispersion modelling for more accurate simulations of the impacts of a plant.

In this view, the compensation strategy of a new WtE project should include the total effect of primary and secondary emissions in order to evaluate the overall effect of the new plant. Technical and economical compensation strategies for the reduction of the emissions also includes the possibility of acquiring and closing existing factories that constitute an existing source of local pollution, or including secondary emissions, never before considered. In this sense it is desirable to start monitoring these emissions to include them in emission inventories from specific sectors.

Finally, in the compensation strategy, it is possible to include also the $\mathrm{CO}_{2}$ balance of the new project, in order to parameterise the compensation choices also on the basis of a parameter of fundamental importance for achieving the objectives of the Paris agreement.

\section{ACKNOWLEDGEMENTS}

The authors wish to thank Mr. Patrick Santini (PA Holding Spa) for the financial support for the preliminary activities related to this work and Dr. Gianluca Antonacci (CISMA Srl) for his scientific contribution to the development of the preliminary balances.

\section{REFERENCES}

[1] Klinghoffer, N.B. \& Castaldi, M.J., (eds.), Waste to Energy Conversion Technology, Woodhead Publishing: Cambridge, 2013.

[2] Rada E.C., Energy from municipal solid waste, WIT Transactions on Ecology and the Environment, 190(2), pp. 945-958, 2014.

[3] Malinauskaite, J., Jouhara, H., Czajczyńska, D., Stanchev, P., Katsou, E., Rostkowski, P., Thorne, R.J., Colón, J., Ponsá, S., Al-Mansour, F., Anguilano, L., Krzyżyńska, R., López, I.C., Vlasopoulos, A. \& Spencer, N., Municipal solid waste management and waste-to-energy in the context of a circular economy and energy recycling in Europe. Energy, 141, pp. 2013-2044, 2017.

[4] Putna, O., Kropáč, J., Fryba, L. \& Pavlas, M. Prediction of heating value of waste and its importance for conceptual development of new waste-to-energy plants, Chemical Engineering Transactions, 39, pp. 1273-1278, 2014.

[5] Tomić, T. \& Schneider, D.R., The role of energy from waste in circular economy and closing the loop concept - energy analysis approach. Renewable and Sustainable Energy Reviews, 98, pp. 268-287, 2018.

[6] Rada E.C., Special waste valorization and renewable energy generation under a circular economy: which priorities?, WIT Transactions on Ecology and the Environment, 222, pp. 145-157, 2019. 
[7] Ribeiro, A., Soares, M., Castro, C., Mota, A., Araujo, J., Vilarinho, C., Carvalho, J., Waste-to-energy technologies applied for refuse derived fuel (RDF) valorisation, Lecture Notes in Electrical Engineering, 505, pp. 641-647, 2019.

[8] Ferronato, N., Rada, E.C., Gorritty Portillo, M.A., Cioca, L.I., Ragazzi, M. \& Torretta, $\mathrm{V}$., Introduction of the circular economy within developing regions: a comparative analysis of advantages and opportunities for waste valorization. Journal of Environmental Management, 230, pp. 366-378, 2019.

[9] Michelini, G., Moraes, R.N., Cunha, R.N., Costa, J.M.H. \& Ometto, A.R., From linear to circular economy: PSS conducting the transition. Procedia CIRP, 64, pp. 2-6, 2017.

[10] Schroeder, P., Anggraeni, K., Weber, U., The Relevance of circular economy practices to the sustainable development goals, Journal of Industrial Ecology, 23(1), pp. 77-95

[11] Rada, E.C., Ragazzi, M., Torretta, V., Castagna, G., Adami, L. \& Cioca, L.I., Circular economy and waste to energy. AIP Conference Proceedings, 1968, pp. 030050, 2018.

[12] Lausselet, C., Cherubini, F., Oreggioni, G.D., del Alamo Serrano, G., Becidan, M., Hu, X., Rørstad, P.K. \& Strømman, A.H., Norwegian waste-to-energy: climate change, circular economy and carbon capture and storage, Resources, Conservation and Recycling, 126, 50-61, 2017.

[13] Incineration of Waste and Reported Human Health Effects; Health Protection Scotland, Online. https://www.hps.scot.nhs.uk/resourcedocument.aspx?id=339 (accessed 11 January 2019).

[14] Stehel, V., Dvořák, J., Wittlingerová, Z., \& Petruželková, A., Economic contradictions of the waste-to-energy concept and emissions reduction plan (case study, Czech Republic), Energy Sources, Part A: Recovery, Utilization and Environmental Effects, 41(13), pp. 1622-1629, 2019.

[15] Ionescu, G., Zardi, D., Tirler, W., Rada, E.C., Ragazzi, M.M., A critical analysis of emissions and atmospheric dispersion of pollutants from plants for the treatment of residual municipal solid waste, UPB Scientific Bulletin, Series D, 74(4), pp. 227-240, 2012.

[16] Saghir, M., Rehan, M. \& Nizami, A.S., Recent trends in gasification based waste-to-energy. Gasification for Low-grade Feedstock, ed. Y. Yun, IntechOpen, pp. 97-114, 2017.

[17] Yepes Maya, D.M., Espinosa Sarmiento, A.L., Vilas Bôas de Sales Oliveira, C.A, Silva Lora, E.E. \& Vieira Andrade, R., Gasification of municipal solid waste for power generation in Brazil, a review of available technologies and their environmental benefits. Journal of Chemistry and Chemical Engineering, 10, pp. 249-255, 2016.

[18] Aurell, J., Barnes, M., Gullett, B.K., Holder, A. \& Eninger, R., Methodology for characterizing emissions from small (0.5-2 MTD) batch-fed gasification systems using multiple waste compositions, Waste Management, 87, pp. 398-406

[19] European Union, Directive 2010/75/EU of the European Parliament and of the Council of 24 November 2010 on industrial emissions (integrated pollution prevention and control). Official Journal of the European Union, Document 32010L0075.

[20] European Union, Directive 2014/52/EU of the European Parliament and of the Council of 16 April 2014 amending Directive 2011/92/EU on the assessment of the effects of certain public and private projects on the environment Text with EEA relevance. Official Journal of the European Union, Document 32014L0052.

[21] European Union, Directive 2011/92/EU of the European Parliament and of the Council of 13 December 2011 on the assessment of the effects of certain public and private projects on the environment Text with EEA relevance. Official Journal of the European Union, Document 32011L0092. 
[22] Arabadjieva, K., 'Better Regulation' in environmental impact assessment: the amended EIA directive. Journal of Environmental Law, 28(1), pp. 159-168, 2016.

[23] Lourdes M.C., \& Sheate W.R. Cumulative effects assessment: a review of UK environmental impact statements, Environmental Impact Assessment Review, 22(4), pp. 415-439, 2002.

[24] European Union, Directive 85/337/EEC of 27 June 1985 on the assessment of the effects of certain public and private projects on the environment. Official Journal of the European Union, Document 31985L0337.

[25] Archivio procedure VIA; Agenzia Provinciale per l'Ambiente e la Tutela del Clima, Online. http://www.provinz.bz.it/service/resdownload.aspx?source=VIA-UVP\&ID=7 87DAEBC7B6D89A4E050960A253242DC (accessed 20 February 2019).

[26] Google Earth Pro. (accessed 19 February 2019).

[27] Lober, D. J., \& Green, D. P., NIMBY or NIABY: a logit model of opposition to solidwaste-disposal facility siting. Journal of Environmental Management, 40(1), pp. 33-50, 1994.

[28] Ren, X., Che, Y., Yang, K., \& Tao, Y., Risk perception and public acceptance toward a highly protested waste-to-energy facility. Waste Management, 48, pp. 528-539, 2016. 